\title{
Characterization of Ceramic Filled Polymer Matrix Composite Used for Biomedical Applications
}

\author{
Waleed Asim Hanna ${ }^{1 *}$, Faiza E. Gharib ${ }^{2}$, Ismail Ibrahim Marhoon ${ }^{3}$ \\ ${ }^{1}$ Materials Engineering Department, University of Technology, Baghdad-Iraq. \\ ${ }^{2}$ Environmental Engineering Department, College of Engineering, Al-Mustansiriya University, \\ Baghdad-Iraq . \\ ${ }^{3}$ Materials Engineering Department, College of Engineering, Al-Mustansiriya University, \\ Baghdad-Iraq \\ *Corresponding author: alnasir69@yahoo.com
}

\begin{abstract}
A particulate composite material was prepared by adding $\left(\mathrm{CaCO}_{3}, \mathrm{CaO}, \mathrm{MgCO}, \mathrm{MgO}\right)$ ceramic particles with particle size of $(<53 \mu \mathrm{m})$ to unsaturated polyester resin with weight fraction of $(3$, $6,9,12,15) \%$ and fixed amount of $\mathrm{CaF}_{2}(0.5 \% \mathrm{wt}$.). The results had revealed that the maximum values of tensile strength, compression, bending strength, hardness, impact energy and water absorption\%, were $\left(57.6828 \mathrm{~N} / \mathrm{mm}^{2}\right.$ at $3 \%$ wt. $\mathrm{CaCO}_{3}, 124.0965 \mathrm{~N} / \mathrm{mm}^{2}$ at $9 \%$ wt. $\mathrm{CaCO}_{3}$, $102.188 \mathrm{~N} / \mathrm{mm}^{2}$ at $9 \%$ wt. $\mathrm{MgO}, 88.2$ Shore $\mathrm{D}$ at $9 \% \mathrm{wt} . \mathrm{CaCO}_{3}, 0.27 \mathrm{~J}$ at $6 \%$ wt. $\mathrm{CaCO}_{3}$ and $0.8432 \%$ at $15 \%$ wt.CaO) compared with reference values, i.e.( $37.4742 \mathrm{~N} / \mathrm{mm}^{2}, 100.3563$ $\mathrm{N} / \mathrm{mm}^{2}, 34.194 \mathrm{~N} / \mathrm{mm}^{2}, 83$ Shore $\mathrm{D}, 0.36 \mathrm{~J}$ and $0.2626 \%$ ) respectively.
\end{abstract}

Key Words: Bio-composites, Unsaturated Polyesters-matrix composite bio-material, Polymermatrix bio- material, Mechanical properties of bio-composites.

\section{INTRODUCTION}

Materials that interface with biological entities are used to create prosthesis, medical devices and replace natural body tissue are broadly called as biomaterials [1]. The use of biodegradable polyesters in orthopedic devices for proper fixation for long bone fractures was first clinically implemented in Finland in 1984. It was demonstrated that the exact union of the fracture fixed by poly(lactic-co glycolic acid) (PLGA) was 5 days faster than the fracture fixed by conventional metallic implants. Since the 1990s, the applications of poly(glycolic acid) (PGA), poly(lactic acid) (PLA), and their copolymers (PLGA) in bone tissue engineering have been investigated extensively [2]. There are two types of biodegradable polymers: The natural-based materials are one category and the second category, synthetic biodegradable polymers. Synthetic polymers can be produced under controlled conditions and therefore exhibit in general predictable and reproducible mechanical and physical properties such as tensile strength, elastic modulus and 
degradation rate. A further advantage is the control of material impurities [3]. Biomaterials have evolved during the past 50 years, and can now be considered "third-generation biomaterials".

Typically, biomaterials can be divided into: polymers, metals, ceramics and natural materials. Composite biomaterials are created by combining two or more of these fields [4]. Currently, composites of polymers and ceramics are being developed with the aim to increase the mechanical scaffold stability and to improve tissue interaction [5]. In addition, efforts have also been invested in developing scaffolds with a drug-delivery capacity. These scaffolds can locally release growth factors or antibiotics and enhance bone ingrowth to treat bone defects and even support wounds healing [6]. Polyester is a very promising biomaterial for biomedical applications, but its reliability, strength and fracture toughness exclude its application as single material for implants i.e. it has very low mechanical properties, unless these properties are modified by controlling the stages of syntheses or by using additives. Generally the main troubles that may limit the use of unsaturated polyester polymers are, they are weak and their intermediate degradation products by non-enzymatic hydrolysis of ester bonds in their backbone reduces the local $\mathrm{pH}$, which in turn induces an inflammatory reaction and damages bone cell health at the implant site.

Moreover, the rapid drop of $\mathrm{pH}$ in vivo may accelerate the polymer's degradation rate, thus, resulting in premature loss of mechanical properties before new bone formation occurs. The polymer acidity is to be regulated by normalizing. In this light, adding an additives of an alkaline nature like carbonates or their oxides to polyester can provide a $\mathrm{pH}$ buffering effect at the polymer surface and, thus, avoid an unfavorable environment for new bone growth. Also, these additives may play an important role in improving the engineering properties of unsaturated polyester considering its effects as filler modifiers. This work is focusing on studying the addition effect of $\mathrm{CaCO}_{3}$ and $\mathrm{MgCO}_{3}$ in the range of (3-15) \% wt. or their related oxides i.e. $\mathrm{CaO}$ , $\mathrm{MgO}$ and fixed amount of $\mathrm{CaF}_{2}(0.5 \%$ wt.) on some mechanical and physical properties i.e. (Tensile and Compression, Bending, Toughness, Hardness and Water absorption) of the unsaturated polyester.

\section{EXPERIMENTAL PART}

a. The masses of the filler materials (Calcium oxide $(\mathrm{CaO})$, Calcium carbonates $\left(\mathrm{CaCO}_{3}\right)$, Magnesium oxide $(\mathrm{MgO})$ and Magnesium carbonates $\left(\mathrm{MgCO}_{3}\right)$. were calculated according to the required weight fractions of the filler materials which were $(3,6,9,12$, 15) wt $\%$. of polymer resin, except for $\mathrm{CaF}_{2}$ that be $0.5 \%$ wt fixed with all fillers.

b. The masses of the resin (unsaturated polyester) were calculated according to the required volume of cast, the accelerator and the hardener, were added as weight $\%$ with an amount of $(0.5 \%)$ and $(2 \%)$ respectively.

c. The required amount of $\mathrm{CaF}_{2}$ is mixed thoroughly with the filler quantity for 30 minutes .

d. The filler of $\left(\mathrm{CaO}, \mathrm{CaCO}_{3}, \mathrm{MgO}\right.$ and $\left.\mathrm{MgCO}_{3}\right)$ and the matrix were mixed for about 20 minute at room temperature continuously and slowly to avoid bubbling during mixing, and then the hardener was added to the mixture with gentle mixing.

e. The mixture was poured from one corner into the mould (to avoid bubbles formation 
which causes cast damage) and the uniform pouring is continued until the mould is filled to the required level.

f. The mould was placed on an electrical vibrator to remove any residual bubbles (i.e. captured gases that evaporate during mixing and temperature rise) and to guarantee the distribution of the cast inside the mould.

g. The mixture was left in the mould for (24) hrs at room temperature to solidify. Then the cast was placed inside a dryer oven over night at $(45)^{\circ} \mathrm{C}$. This step was important to reveal complete polymerization, best coherency, and to relieve residual stresses.

h. The specimens were cut according to the standard dimensions for each test, using different cutting tools, i.e., (tensile, compression, bending, impact, hardness and water absorption) tests.

i. Water absorption test was performed according to (ASTM D 570- 98). Tensile test was performed according to (ASTM D638M- 87b) [7, 8]. Compression test was performed according to (ASTM D695- 85) [7, 8]. Flexural strength test was performed according to (ASTM D790). Impact test was performed according to (ISO- 180) [9]. Hardness test was performed by using shore hardness (D) and according to (ASTM D 2240). Knowing that all tests were accomplished at room temperature.

\section{RESULTS AND DISCUSSION}

\subsection{Mechanical Evaluation:}

\subsubsection{Tensile strength}

Figure (1) shows the relationship between the tensile strength and the weight fraction of the filler particles of $\left(\mathrm{CaCO}_{3}, \mathrm{CaO}, \mathrm{MgCO}_{3}\right.$ and $\left.\mathrm{MgO}\right)$ which were added to the unsaturated polyester resin, respectively. It's obvious that the addition of $\left(\mathrm{CaCO}_{3}\right.$ and $\left.\mathrm{MgO}\right)$ filler particles has a noticeable effect on the tensile strength more than the $\left(\mathrm{MgCO}_{3}\right.$ and $\left.\mathrm{CaO}\right)$, and the maximum tensile strength of $\left(\mathrm{CaCO}_{3}\right.$ reaches $57.6828 \mathrm{~N} / \mathrm{mm}^{2}$ at $\left.3 \% \mathrm{wt}\right)$ and $\left(46.107 \mathrm{~N} / \mathrm{mm}^{2}\right.$ at $9 \% \mathrm{wt}$ for addition of $\mathrm{MgO}$ ) compared to the tensile strength of the reference which is equal to $\left(37.4742 \mathrm{~N} / \mathrm{mm}^{2}\right)$. This means that weight\% represents critical weight fraction, beyond which the strength decreases with increase in filler content.

This decrease in strength may be due to non-wetting of the filler particles with the matrix and may be due to the non-uniform distribution of the particles [10] as a result of excessive particles that were not well dispersed in the polymer creating stress concentrations in the polymer matrix and decrease the tensile strength [11].

It is observed that, the $\left(\mathrm{MgCO}_{3}\right.$ and $\left.\mathrm{CaO}\right)$ specimens exhibits lower tensile as the filler content increases in the unsaturated resin. This may be due to the rigidity of the composite increased with increase in content of $\left(\mathrm{MgCO}_{3}\right.$ and $\left.\mathrm{CaO}\right)$ filler particles in the composite [12]. Also the $\mathrm{CaO}$ specimen exhibits lowest tensile strength compared to other specimens this may be due to larger particle size [13] or $\mathrm{CaO}$ filler particles have hygroscopic properties, during fabrication 
when it is added to unsaturated polyester resin, that lead to form a high viscose mixture (viscosity increase directly with weight fraction) that lead to decrease resin wettability in turn affected in resultant mechanical properties of composite.



Figure (1) the relationship between the tensile strength and the weight fraction of the filler particles at a range of (3-15) \%wt.

\subsubsection{Elongation percentage}

Figure (2) shows the relationship between the elongation percentage calculated at break point and the weight fraction of the filler particles of $\left(\mathrm{CaCO}_{3}, \mathrm{CaO}, \mathrm{MgCO}_{3}\right.$ and $\left.\mathrm{MgO}\right)$, which were added to the unsaturated polyester resin, respectively. The figure shows the elongation percentage decreasing with the increasing weight fraction of filler particles for all groups of composite materials. The results had revealed that the maximum amount of elongation percentage at break $\left(1.863 \%\right.$ at $3 \%$ wt. of $\mathrm{CaCO}_{3} ; 0.735 \%$ at $6 \%$ wt. of $\mathrm{CaO} ; 0.7843 \%$ at $3 \%$ wt. of $\mathrm{MgCO}_{3}$ and $1.951 \%$ at $3 \%$ wt. of $\mathrm{MgO}$ ) compared with the elongation percentage at break of the reference which is equal to $(2.5 \%)$. This is because of increasing the particle content, which will act as localized stress concentration regions, so the elongation percentage at break will be decreased. Also, elongation properties as seen from Figure (2) decrease with the addition of filler that indicate an interference by the filler in the mobility or deformability of the matrix $[14,15]$. This interference is created through the physical interaction and immobilization of the polymer matrix by the presence of mechanical restraints. So as the filler concentration increases, the elongation at break gets reduced $[14,16]$. The elongation percentages at break for the composite material filled with $\left(\mathrm{MgCO}_{3}\right.$ and $\left.\mathrm{CaO}\right)$ particles are lower than the same percentages for the composite material filled with $\left(\mathrm{CaCO}_{3}\right.$ and $\left.\mathrm{MgO}\right)$ particles. This is due to the effect of particle size difference, large particles have low surface area, of $\mathrm{CaO}$ and hygroscopic property that were mentioned before and weak interface between particles and polymer for $\mathrm{MgCO}_{3}$. 


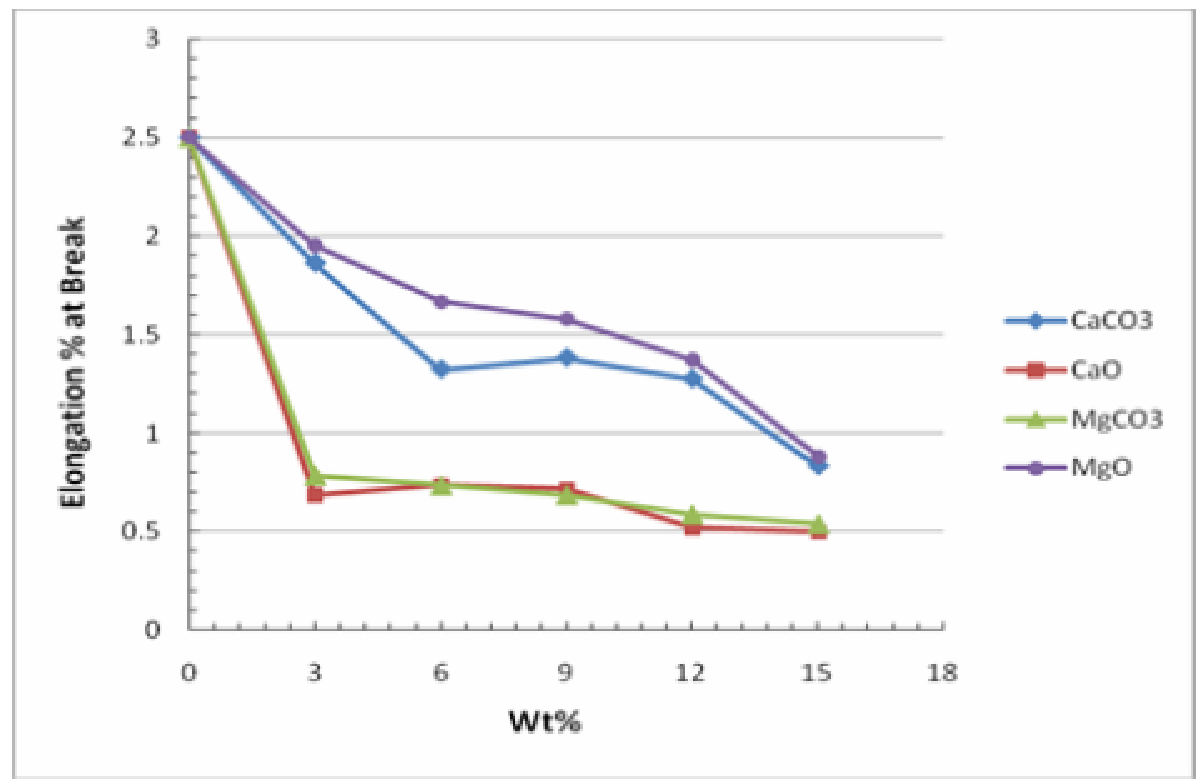

Figure (2): The relationship between the elongation percentage at break point and the weight fraction of the filler particles at a range of (3-15) \%wt.

\subsubsection{Tensile modulus}

Figure (3) illustrates the tensile modulus of elasticity increasing with increasing weight fraction of filler particles for all groups of composite materials. The increase in tensile modulus of elasticity may be also due to the high elastic modulus of the filler material $\left(35 \mathrm{GPa}\right.$ of $\mathrm{CaCO}_{3}$ and $\mathrm{MgCO}_{3} ; 38-66.3 \mathrm{GPa}$ of $\mathrm{CaO} ; 250-300 \mathrm{GPa}$ of $\mathrm{MgO} ; 108-110 \mathrm{GPa}$ of $\mathrm{CaF}_{2}$ ) compared with that ( $3 \mathrm{GPa})$ of the matrix material [17]. Also, elongation properties decreased with the addition of filler indicating interference by the filler in the mobility or deformability of the matrix [14] and in turn lead to strain reduction with increasing weight fraction. The tensile modulus of elasticity reaches its maximum amount at $\left(5706.183\right.$ of $\mathrm{CaCO}_{3} ; 5003.1$ for $\mathrm{CaO} ; 7949.37 \mathrm{MgCO}_{3}$; 5266.421 of $\mathrm{MgO}$ ) $\mathrm{N} / \mathrm{mm}^{2}$ at addition weight fraction of $15 \%$ wt. compared to the tensile modulus of the reference which is equal to $\left(2401.488 \mathrm{~N} / \mathrm{mm}^{2}\right)$.

\subsubsection{Compression strength}

Figure (4) shows the relationship between the compression strength and the weight fraction of the additive particles of $\left(\mathrm{CaCO}_{3}, \mathrm{CaO}, \mathrm{MgCO}_{3}\right.$ and $\left.\mathrm{MgO}\right)$ to the unsaturated polyester resin, respectively. The results had revealed that the maximum amount of compression strength $\left(124.0965 \mathrm{~N} / \mathrm{mm}^{2}\right.$ at $9 \%$ wt. of $\mathrm{CaCO}_{3} ; 88.90 \mathrm{~N} / \mathrm{mm}^{2}$ at $3 \%$ wt. of $\mathrm{CaO} ; 112.815 \mathrm{~N} / \mathrm{mm}^{2}$ at $15 \%$ wt. of $\mathrm{MgCO}_{3}$ and $115.2675 \mathrm{~N} / \mathrm{mm}^{2}$ at $6 \%$ wt. of $\mathrm{MgO}$ ) compared with the compression at fracture of the reference which is equal to $\left(100.3563 \mathrm{~N} / \mathrm{mm}^{2}\right)$ that can explain fillers particulate work at the outset on impeding the cracks movement, where that lead to increase in compression strength values. After ( $9 \%$ wt. $\mathrm{CaCO}_{3}$ and $6 \%$ wt. $\mathrm{MgO}$ ), the compression strength decreases with further additional increase. This may be related to increase in the viscosity of the liquid at high rates of these fillers, causing difficulty in matrix fluidity and reduced ability to penetration between fillers (increase in surface energy of matrix) which reduces filler wetting, also adhesion decreases between the matrix and fillers, as a result of reduction in wetting, and the emergence of 
a lot of flaws and gaps within the prepared composite material that will be formed. On the basis of the above, it will lead to decrease in compression strength at high rates of fillers. The decreased compression strength with $\mathrm{CaO}$ filler can be explained as due to $\mathrm{CaO}$ hygroscopic properties. during fabrication when it is added to unsaturated polyester resin leads to form a high viscose mixture (viscosity increase directly with weight fraction) that lead to decrease in resin wettability and in turn affect the in resultant mechanical properties of composite. Again, it can be noted that the addition of $\mathrm{CaCO}_{3}$ filler particles improves the compression strength more than the addition of other fillers particles.

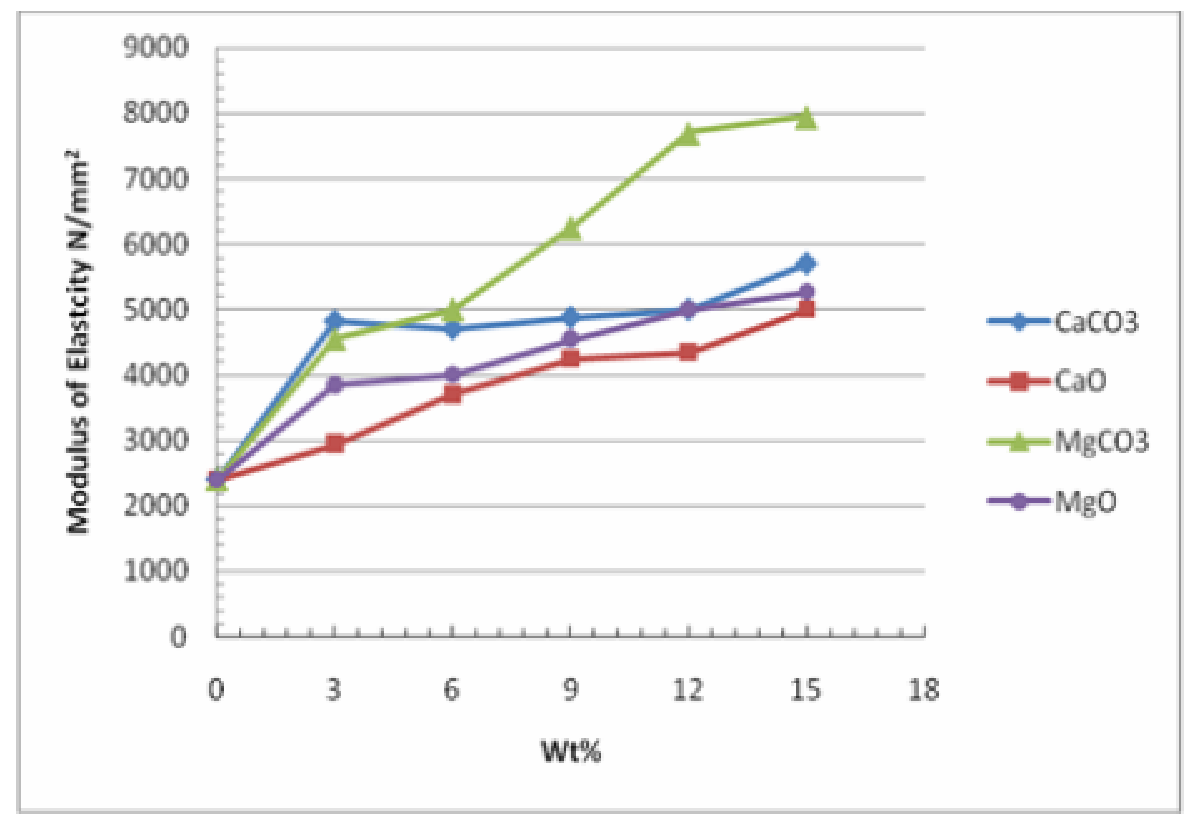

Figure (3): The relationship between the Modulus of elasticity and the weight fraction of the filler particles at a range of (3-15) \%wt.



Figure (4): the relationship between compression stress at fracture and the weight fraction of the filler particles at a range of (3-15) \%wt. 


\subsubsection{Bending strength}

Figure (5) shows the relationship between the bending strength (Flexural Strength $\left(\sigma_{\mathrm{f}}\right)$ ) and the weight fraction of the filler particles of $\left(\mathrm{CaCO}_{3}, \mathrm{CaO}, \mathrm{MgCO}_{3}\right.$ and $\left.\mathrm{MgO}\right)$ powder, which were added to the unsaturated polyester resin, respectively. The results had revealed that the maximum

amount of bending strength $\left(97.864 \mathrm{~N} / \mathrm{mm}^{2}\right.$ at $15 \mathrm{wt} \%$ of $\left.\mathrm{CaCO}_{3}\right) ;\left(75.462 \mathrm{~N} / \mathrm{mm}^{2}\right.$ at $9 \mathrm{wt} \%$ of $\mathrm{MgCO}_{3}$ ); (for $\mathrm{CaO}$ filler, bending strength data distributed around average value of 34.521 $\left.\mathrm{N} / \mathrm{mm}^{2} \pm 3.33\right) ;\left(102.188 \mathrm{~N} / \mathrm{mm}^{2}\right.$ at $\left.9 \mathrm{wt} \% \mathrm{MgO}\right)$; compared to the bending strength of the reference which is equal to $\left(34.194 \mathrm{~N} / \mathrm{mm}^{2}\right)$. The increase in bending strength may be also due to the high elastic modulus of the filler material compared with that of the matrix material. The decrease in the bending strength after adding ( 9 wt. \%) of $\mathrm{MgCO}_{3}$ and $\mathrm{MgO}$ fillers can be related to the decrease in the wettability that was mentioned before, especially the bending strength largely depends on the bonding force between the matrix and the filler material(interaction) and may be due to the nonuniform distribution of the particles.

The non observed improvement in bending strength when $\mathrm{CaO}$ was added, may due to the hygroscopic properties, during fabrication when it added to unsaturated polyester resin, that lead to formation of a high viscose mixture (viscosity increases directly with weight fraction) that lead to decreased resin wettability in turn affecting resultant mechanical properties of composite. The composite material containing $\mathrm{MgO}$ filler particles has shown a greater bending strength than the other filler particles.

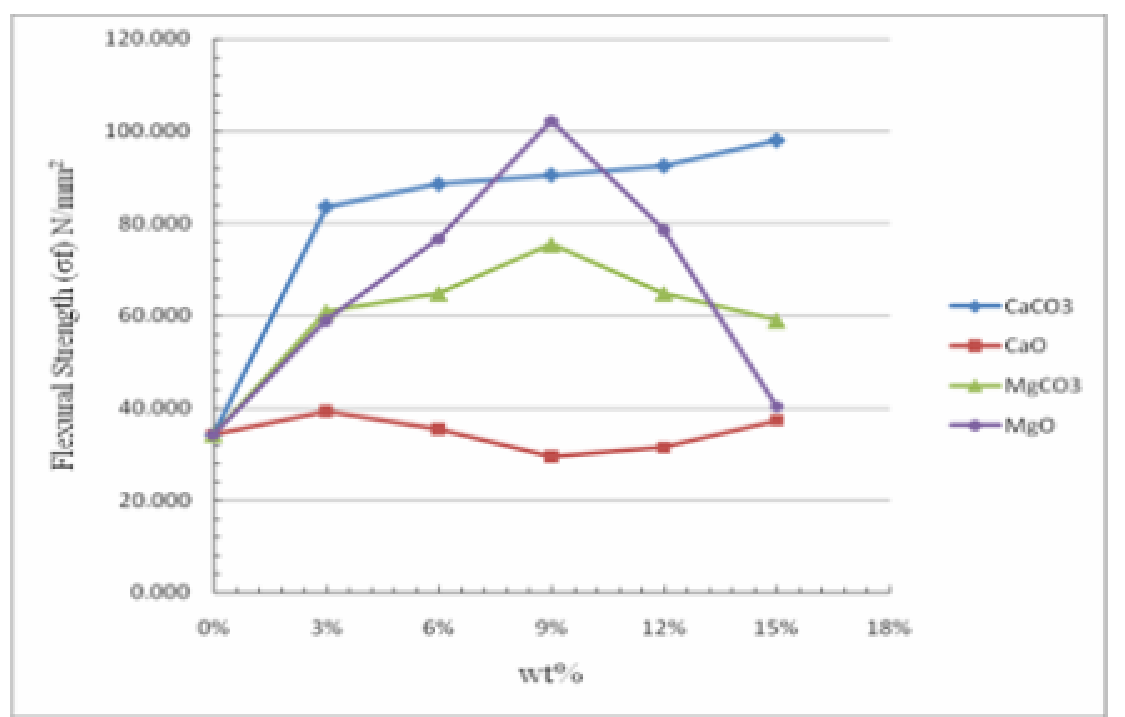

Figure (5): the relationship between the Flexural Strength $\left(\sigma_{\mathrm{f}}\right)$ and the weight fraction of the filler particles at a range of (3-15) \%wt.

\subsubsection{Bending modulus}

Figure (6) illustrates the bending modulus that increases with increasing weight fraction of $\left(\mathrm{CaCO}_{3} ; \mathrm{CaO} ; \mathrm{MgCO}_{3}\right.$ and $\left.\mathrm{MgO}\right)$ filler particles, and reaches its maximum amount (4890.928 of $\mathrm{CaCO}_{3} ; 4366.9$ for $\mathrm{CaO} ; 6718.308$ of $\mathrm{MgCO}_{3} ; 5764.308$ of $\left.\mathrm{MgO}\right) \mathrm{N} / \mathrm{mm}^{2}$ at addition weight 
fraction of $15 \%$ wt. compared to the bending modulus of the reference which is equal to $\left(2570.1486 \mathrm{~N} / \mathrm{mm}^{2}\right)$.The increase in bending modulus may be also due to the high elastic modulus of the filler material compared with that of the matrix material [17].

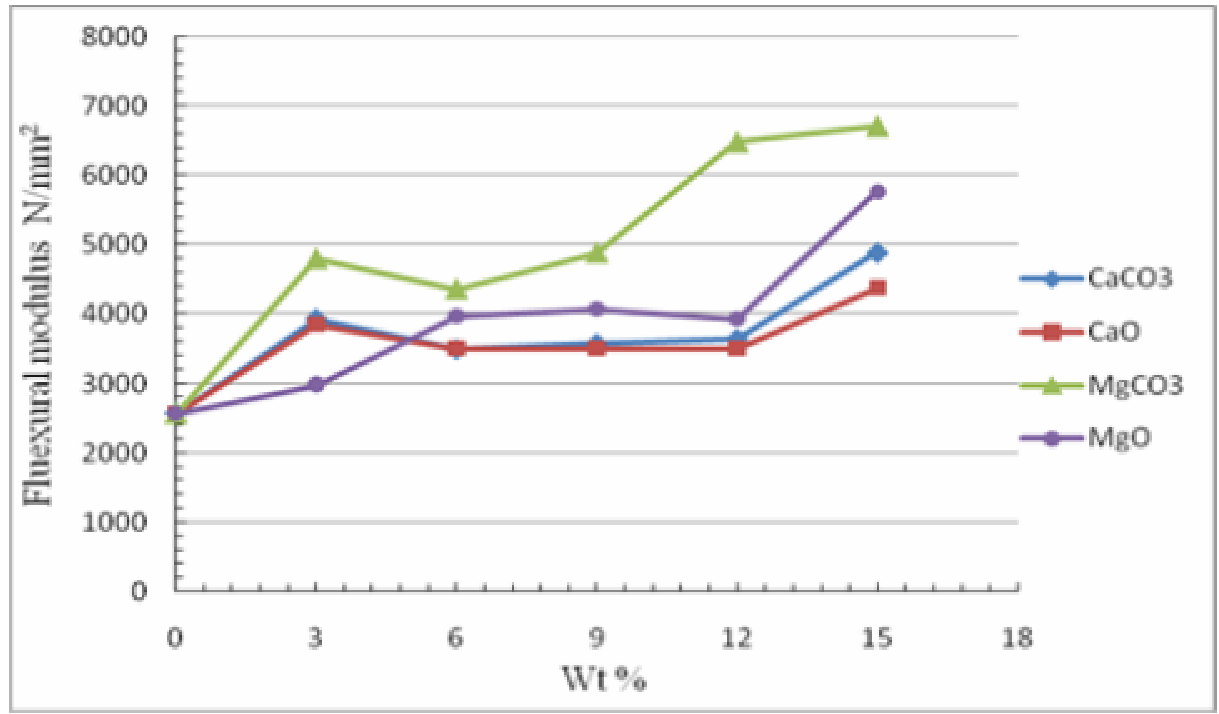

Figure (6): the relationship between the Flexural modulus and the weight fraction of the filler particles at a range of (3-15) \%wt.

\subsubsection{Hardness}

Figure (7) shows the relationship between hardness and weight fraction of the filler particles of $\left(\mathrm{CaCO}_{3}, \mathrm{CaO}, \mathrm{MgCO}_{3}\right.$ and $\left.\mathrm{MgO}\right)$, which were added to the unsaturated polyester resin, respectively. The results had revealed that the hardness increases with increasing weight fraction of all groups of filler particles, and reaches its maximum amount; i.e. at (88.2 at $9 \%$ wt. of $\mathrm{CaCO}_{3}, 87.2$ at $9 \%$ wt. of $\mathrm{CaO}, 86.8$ at $15 \%$ wt. of $\mathrm{MgCO}_{3}$ and 86.4 at $6 \%$ wt. of $\mathrm{MgO}$ ) compared to the hardness of the reference which is equal to (83) because of increasing wettability or bonding (interaction) between the matrix and the filer particles. But, after addition of (9\% wt.) of $\left(\mathrm{CaCO}_{3}\right.$ and $\left.\mathrm{CaO}\right)$ the composite becomes brittle due to the large content of particles and the hardness decreases. Here, also the composite material containing $\mathrm{CaCO}_{3}$ filler particles has a higher hardness when compared to the other additives.

\subsubsection{Impact energy}

Figure (8) shows the relationship between the impact energy and the weight fraction of the $\left(\mathrm{CaCO}_{3}, \mathrm{CaO}, \mathrm{MgCO}_{3}\right.$ and $\left.\mathrm{MgO}\right)$, which were added to the unsaturated polyester resin, respectively. Results had revealed that the impact energy decreases with increasing weight fraction of filler particles for all groups of composite materials. This is because of the filler particles, which may represent points for a localized stress concentration, from which the failure will begin, or this is mainly due to the reduction of elasticity of material due to filler addition and thereby reducing the deformability of matrix and in turn the ductility in the skin area, so that the composite tends to form a weak structure also. An increase in concentration of filler reduces the 
ability of matrix to absorb energy and thereby reducing the toughness, so impact energy decreases [14]. Also, when results being compared for the four different additives, it can be seen that deformation in impact energy for the base unsaturated polyester composite was less by adding $\mathrm{CaCO}_{3}$, relative to other additives.

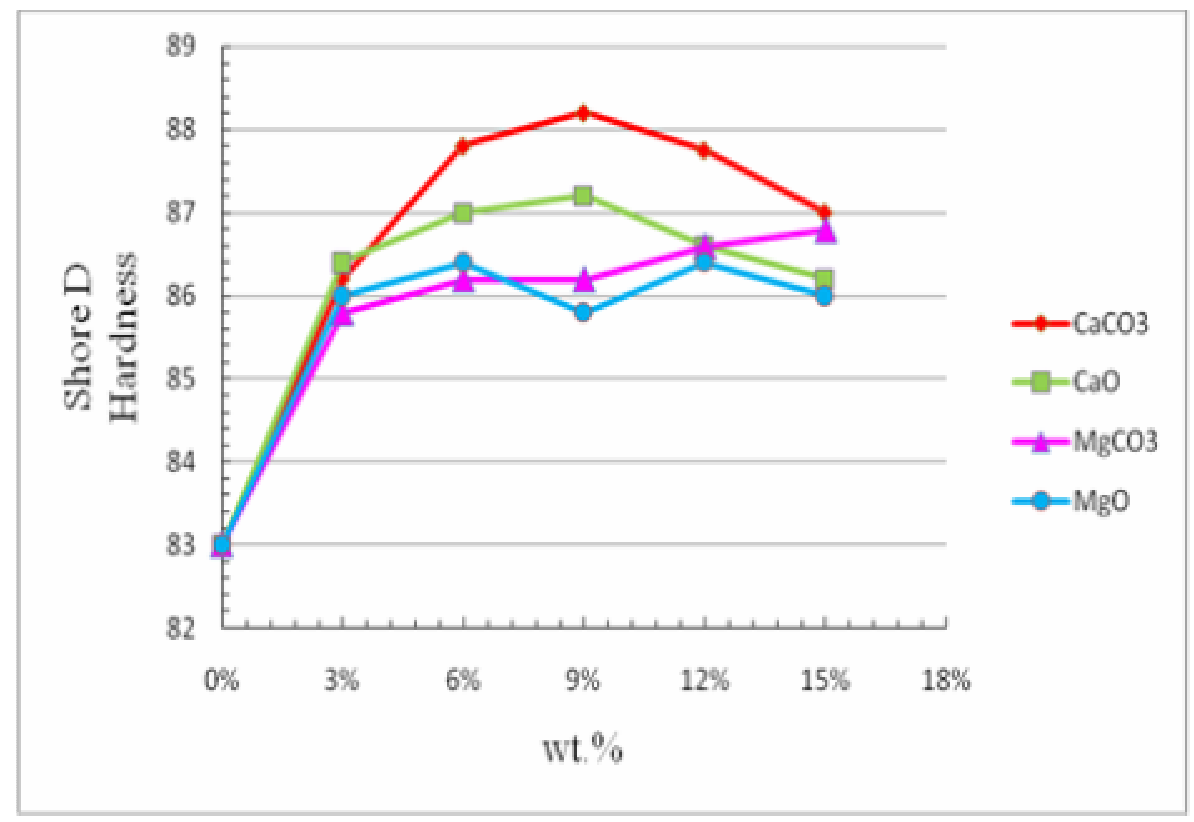

Figure (7): the relationship between the Shore D Hardness and the weight fraction of the filler particles at a range of (3-15) \%wt.

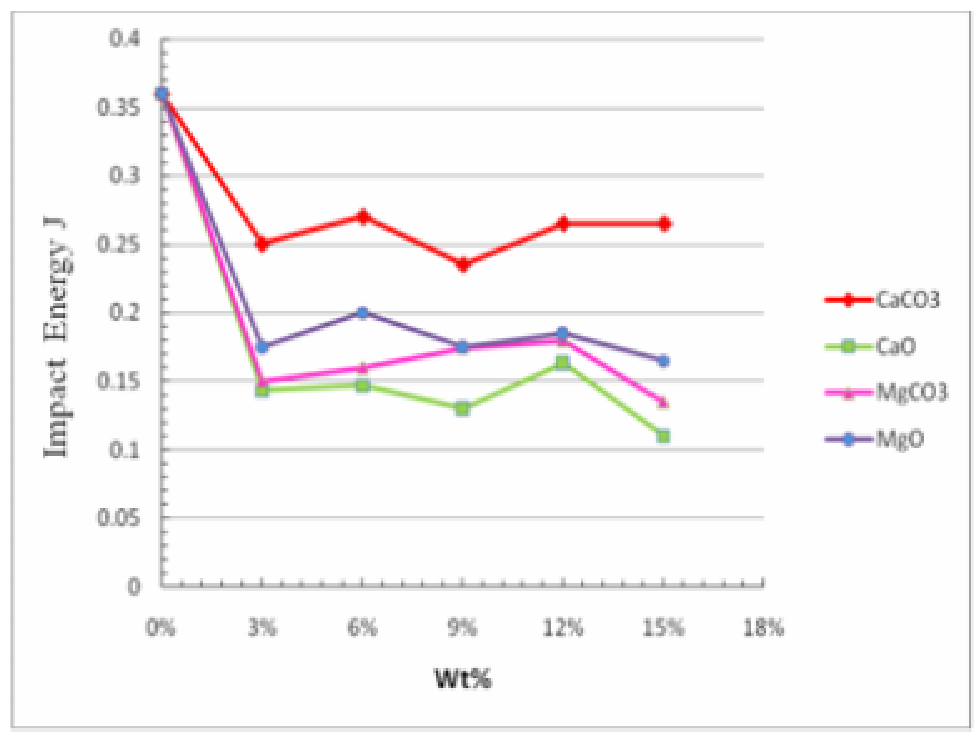

Figure (8): the relationship between the impact energy and the weight fraction of the filler particles at a range of (3-15) \% wt. 


\subsection{Physical Evaluation}

\subsubsection{Water absorption}

Figure (9) shows the relationship between the percent of water absorption and weight fraction of the filler particles of $\left(\mathrm{CaCO}_{3}, \mathrm{CaO}, \mathrm{MgCO}_{3}\right.$ and $\left.\mathrm{MgO}\right)$, which were added to the unsaturated polyester resin, respectively. The results had revealed that the water absorption percentage increases with increasing weight fraction of all filler particles, and reaches its maximum amount $\left(0.3064 \%\right.$ of $\mathrm{CaCO}_{3} ; 0.8432 \%$ for $\mathrm{CaO} ; 0.2572 \%$ of $\mathrm{MgCO}_{3} ; 0.6360 \%$ of $\left.\mathrm{MgO}\right)$ by adding weight fraction of $15 \%$ compared to water absorption percentage of the reference which is equal to $\left(0.2626 \%\right.$ ), except at $6 \%$ wt. of $\mathrm{MgCO}_{3}$, a slight decrease in water absorption is found and this decrease can be related to nature of $\mathrm{MgCO}_{3}$. In general the increases in water absorption percentage with increasing weight fraction of all filler particles may be due to the filler particles which have a higher water absorption percentage than the matrix. In this work the composite material filled with $\mathrm{CaO}, \mathrm{MgO}$ particles shows a higher water absorption percentage when compared with their carbonates i.e. $\mathrm{CaCO}_{3}, \mathrm{MgCO}_{3}$ particles because of the hygroscopic nature of $\mathrm{MgO}$ and $\mathrm{CaO}$, that will affect the water absorption percentage of the composite material.

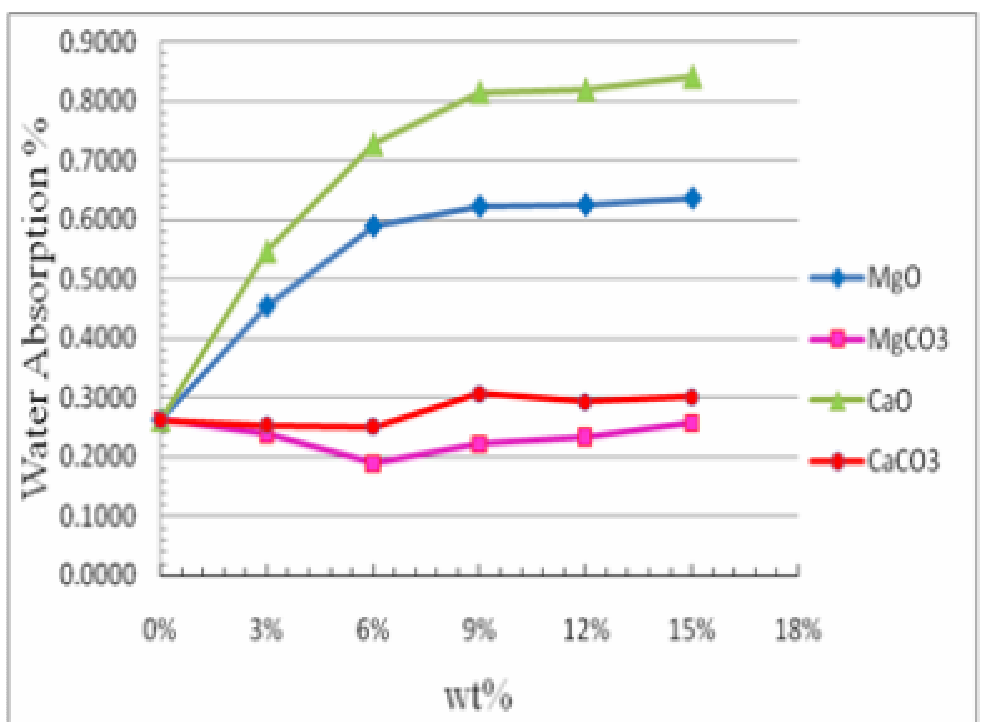

Figure (9): the relationship between water absorption percentage and weight fraction of the filler particles at a range of (3-15)\% wt.

\section{CONCLUSIONS}

The following are the salient observation made from the above investigation.

a. The values of tensile modulus of elasticity, bending modulus, hardness and water absorption percentage will increase with filler percentage for all fillers types.

b. The values of elongation percentage at break and Impact energy had decreased with increase of 
filler percentage for all filler groups.

c. Filling the unsaturated polyester resin by $\mathrm{CaCO}_{3}$ and $\mathrm{MgO}$ filler particles leads to an increase in the ultimate tensile strength as the weight fraction of the filler particles increases and reaches its maximum value of $(57.6828,46.107) \mathrm{N} / \mathrm{mm}^{2}$ at $(3 \%, 9 \%)$ wt. for $\mathrm{CaCO}_{3}$ and $\mathrm{MgO}$ respectively. For $\mathrm{MgCO}_{3}$ and $\mathrm{CaO}$, filler particles it leads to decrease in the ultimate tensile strength as the weight fraction of the filler particles increases.

d. Flexural strength of the prepared composite materials , filled with $\mathrm{CaCO}_{3}, \mathrm{MgCO}_{3}$ and $\mathrm{MgO}$, increases with increasing weight fraction of filler particles while for $\mathrm{MgCO}_{3}$ and $\mathrm{MgO}$ till reaching a maximum value of $(75.462,102.188) \mathrm{N} / \mathrm{mm}^{2}$ at $(9 \% \mathrm{wt})$ for $\mathrm{MgCO}_{3}$ and $\mathrm{MgO}$ respectively. Flexural strength of unsaturated polyester filled with $\mathrm{CaO}$ filler particles has a constant value of $\left(34.521 \mathrm{~N} / \mathrm{mm}^{2} \pm 3.33\right)$ for all weight fractions as compared to reference material (34.194) $\mathrm{N} / \mathrm{mm}^{2}$.

e. The compression strength had increased with increasing weight fraction of $\mathrm{CaCO}_{3}, \mathrm{MgCO}_{3}$ and $\mathrm{MgO}$ filler particles till reaching a maximum value at $\left(124.0965 \mathrm{~N} / \mathrm{mm}^{2}\right.$ at $9 \%$ wt. of $\left.\mathrm{CaCO}_{3}\right),\left(112.815 \mathrm{~N} / \mathrm{mm}^{2}\right.$ at $15 \%$ wt. of $\left.\mathrm{MgCO}_{3}\right)$ and $\left(115.2675 \mathrm{~N} / \mathrm{mm}^{2}\right.$ at $6 \%$ wt. of $\left.\mathrm{MgO}\right)$. Filling unsaturated polyester with $\mathrm{CaO}$ filler particles leads to decrease in the compression strength as the weight fraction of the filler particles increases.

\section{REFERENCES}

1. Williams DF., "Definitions in biomaterials. Proceedings of a consensus conference of the european society for biomaterials", vol. 4. Chester, England, March 3-5, 1986. New York:Elsevier, 1987.

2. Gunatillake PA, Adhikari R, Biodegradable synthetic polymers for tissue engineering. Eur Cell Mater J, 5:1-16, 2003.

3. K. Rezwan, Q.Z. Chen, J.J. Blaker, Aldo Roberto Boccaccini, Biodegradable and bioactive porous polymer/inorganic composite scaffolds for bone tissue engineering, Biomaterials 27 (2006) 3413-3431.

4. Hench LL, Polak JM. Third-Generation Biomedical Materials. Science 2002; 295:1014-1017.

5. Kim HW, Knowles JC, Kim HE. Hydroxyapatite/poly([epsilon]-caprolactone) composite coatings on hydroxyapatite porous bone scaffold for drug delivery. Biomaterials; 25:1279-1287, 2004.

6. Gittens SA, Uludag H. Growth factor delivery for bone tissue engineering. J Drug Target; 9:407-29, 2001.

7. Jaafar Al-Haidari, Engineering Materials Tests, Dar Al-Motaz for publication and distribution, first edition ,Jordan, 2005

8. Qahtan Kahlf Al-Khazraji, Adel Mahmoud Hassan, Abd El Gawad Mohamed Sharif; Engineering materials and their tests; Dar Djlah for publication and distribution, first edition, Jordan ,2009

9. Mohammed Ismail Omar, Quality and plastic materials tests, Dar al-kotob al-ilmiyah for Publishing and Distribution, Lebanon, 2001

10. H. V. Ramakrishna, S. K. Rai ; Effect on the Mechanical Properties and Water Absorption of Granite Powder Composites on Toughening Epoxy with Unsaturated Polyester and 
Unsaturated Polyester with Epoxy Resin; SAGE Publications, Journal of REINFORCED PLASTICS AND COMPOSITES, Vol. 25, No. 1/2006.

11. Ganiyu K. Latinwo, David S. Aribike, Layioye O. Oyekunle2, Akpoveta A. Susu, Semiu A. Kareem ; EFFECTS OF CALCIUM CARBONATE OF DIFFERENT COMPOSITIONS AND PARTICLE SIZE DISTRIBUTIONS ON THE MECHANICAL PROPERTIES OF

FLEXIBLE POLYURETHANE FOAM; Nature and Science 2010;8(9): pages 92-101. (ISSN: 1545-0740).

12. B. Shivamurthy, Siddaramaiah , M.S. Prabhuswamy ; Influence of $\mathrm{SiO}_{2}$ Fillers on Sliding Wear Resistance and Mechanical Properties of Compression Moulded Glass Epoxy Composites ; Journal of Minerals \& Materials Characterization \& Engineering, Vol. 8, No.7, pp 513-530, 2009.

13. M.S. Sreekanth, V.A. Bambole, S.T. Mhaske1, P.A. Mahanwar ; Effect of Particle Size and Concentration of Flyash on Properties of Polyester Thermoplastic Elastomer Composites ; Journal of Minerals \& Materials Characterization \& Engineering, Vol. 8, No.3, pp 237-248, 2009.

14. M. S. Sreekanth1, V. A. Bambole2, S. T. Mhaske1, P. A. Mahanwar ; Effect of Concentration of Mica on Properties of Polyester Thermoplastic Elastomer Composites ; Journal of Minerals \& Materials Characterization \& Engineering, Vol. 8, No.4, pp 271-282, 2009

15. Suryasarathi Bose and P.A.Mahanwar; Effect of Particle Size of Filler on Properties of Nylon-6; Journal of Minerals \& Materials Characterization \& Engineering, Vol. 3, No.1, pp 23-31, 2004.

16. Roger N. Rothon; Editor, Particulate-Filled Polymer Composites, second edition, Rapra Technology Limited, UK,2003.

17. Shao-Yun Fu , Xi-Qiao Feng, Bernd Lauke, Yiu-Wing Mai ,effects of particle size,particle/matrix interface adhesion and particle loading on mechanical properties of particulate-polymer composites, Elsevier, Composites part B 39 (2008) 933-961. 